Digitalizacja archiwalnych numerów czasopisma naukowego Analecta Cracoviensia 1-24 (1969-1992) i ich publikacja w otwartym dostępie - zadanie finansowane w ramach umowy 672/P-DUN/2017 ze środków Ministra Nauki i Szkolnictwa Wyższego przeznaczonych na działalność upowszechniającą naukę

\title{
EUCHARYSTIA I DUCH SWIETY Więź teologicznobiblijna
}

Zmartwychwstały Chrystus odchodząc do Ojca obiecal swoim uczniom, że pozostawi im swego Ducha - Ducha Świętego, który będzie z nimi zawsze $(\mathrm{J} 14,16)$, aby pouczać ich o Bożej Prawdzie i umacniać w życiu aż do powtórnego przyjścia Pana w chwale. W czasie Ostatniej Wieczerzy Zbawiciel ustanowił swoją Pamiątkę, w której chleb i wino stają się Jego Ciałem i krwią - pokarmem i napojem dającym życie wieczne. Te dwa wielkie dary to skarb umożliwiający Kościołowi życie i działanie, źródło apostolskiej siły i nieoceniona obecność Boga wśród ludzi. W naszej pracy postaramy się rozważyć, na ile Pismo Święte daje podstawy do łączenia Ducha Swiętego działającego w Kościele z Eucharystią, zwłaszcza z przeistoczeniem, jako Sprawcy tego przedziwnego działania przemieniającego zwykły pokarm i napój w Ciało i Krew Chrystusa. Ojcowie Wschodni wielokrotnie wyrażali wiarę w to, co wypowiadamy podczas Modlitwy Eucharystycznej, prosząc w epiklezie Ojca, by mocą Ducha uświęcił przygotowane dary, aby mogły się stać Ciałem i Krwią Jego Syna ${ }^{1}$. W ostatnich latach temat więzi Ducha i Eucharystii podjęli J. M. R. Tillard, głównie jako dogmatyk ${ }^{2}$, oraz A. Jankowski, który rozpatrzył biblijne aspekty zagadnienia i zaproponował kierunki dalszych poszukiwań rozwiązania problemu $^{3}$. Idąc po linii wyznaczonej przez obydwu uczonych będziemy starali się

* Artykuł jest streszczeniem głównych myśli rozprawy habilitacyjnej,przedstawionej na Wydziale Teologicznym Papieskiej Akademii Teologicznej w Krakowie w r. 1987.

${ }_{1}^{1}$ Por. P. Evd ok imov, L'Esprit-Saint pensé par les Pères et vécu dans la liturgie, [w:] H. C a zelles, P. Evdokimov, A. Gr ein e r, Lemystére de l'Esprit Saint, Tours 1968, s. 69-109. 102 - 109; J. M. R. Tillard, L'Eucharistie et le Saint-Esprit, „Nouvelle Revue Théologique” 90 (1968) s. 363 - 387. $378-381$. Autorzy przytaczają m. in. teksty św. Jana Damasceńskiego, św. Jana Chryzostoma, św. Cyryla Jerozolimskiego, św. Bazylego, św. Cyryla Aleksandryjskiego, św. Maksyma i Teodoreta z Cyru.

${ }_{2}^{2}$ Zob. wyżej przypis 1 . W oparciu o dane patrystyczne i dzieła późniejszych teologów autor rozważa Eucharystię jako dzieło Chrystusa i Jego Kościoła, udzielające dóbr Ducha w Chrystusie poprzez przyjmowanie Ciała i Krwi Eucharystycznej, które są owocami mocy Ducha Swiętego.

${ }^{3}$ A. J a nk ow sk i, Duch Święty a Eucharystia, „Analecta Cracoviensia” 8(1976) s. 87 - 110. Choć Pismo Święte nie zawiera żadnego tekstu lączącego Ducha Świętego z Eucharystią, można jednak tę więź wykazać na piętrze syntezy właściwej dla teologii biblijnej. Autor zwraca uwagę, że kult w Duchu i prawdzie, zaprowadzony przez Chrystusa-Arcykapłana na wieki za sprawą Ducha Swiętego, jest znamieniem nowej fazy zbawczej ekonomii. Duch Święty powoduje, że Kościół jest nową świątynią i Cialem Chrystusa, przez Niego Bóg powołał Zmartwychwstałego Pana do 
zwrócić uwagę na niektóre teksty oraz idee biblijne mogące stanowić podstawę do łączenia Ducha Świętego i Eucharystii.

OSOBA I MISJA JEZUSA CHRYSTUSA

SPEŁNIENIEM ZAPOWIEDZI STAREGO PRZYMIERZA O NOWYM KULCIE W DUCHU JAHWE

Pewnych zapowiedzi nowego, doskonałego kultu, jaki będzie sprawowany w przyszłości zgodnie z Bożymi wymaganiami, czyli według jego Ducha, można doszukać się już w tekstach Starego Testamentu przedstawiających kolejne etapy dziejów zbawienia. Obrzędy sprawowane w przenośnym przybytku podczas wędrówki po pustyni przedstawione są jako odpowiadające dokładnie wzorcom ukazanym Mojżeszowi „na górze” 4 w specjalnym objawieniu, czyli w wyniku działania Bożego ducha (por. Lb 11,17), który dopiero w Nowym Testamencie zostanie objawiony jako Trzecia Osoba Boska.

Uczty ofiarne, stanowiące rodzaj komunii z bóstwem ${ }^{5}$ są w Starym Testamencie znakiem jedności człowieka - członka Narodu Wybranego - z Bogiem, który zawarł z nim Przymierze. Szczególne miejsce wśród ofiar Starego Przymierza zajmuje baranek paschalny składany na pamiątkę wyjścia z Egiptu, ocalenia od plagi zagłady pierworodnych, przeprowadzenia Izraelitów przez Morze Czerwone i jednocześnie zapowiedź nowej Paschy, ofiary nowego Baranka, który przeszedł przez śmierć aby wszystkim zapewnić nowe życie ${ }^{6}$. Dla zrozumienia, czym jest Eucharystia jako pamiątka Paschy Jezusa Chrystusa, niezwykle ważne jest uświadomienie sobie, czym była dla Izraelitów Pascha - pamiątka głównego wydarzenia w dziejach ich narodu i religii. Hebrajski termin zikkârôn i jego grecki odpowiednik anámnēsis (por. np. Wj 12,14; Lb $10,10)$ oznacza wspomnienie uobecniające, powodujące przeżywanie na nowo tego, co wydarzyło się w przeszłości. Izraelici obchodzący Paschę uważali, że sami uczestniczą w tym, co oznaczają paschalne zwyczaje ujęte w ściśle przestrzegany rytual ${ }^{7}$. Dla myślących takimi kategoriami ludzi znak Eucharystiiprawdziwego Ciała i Krwi Jezusa Chrystusa, złożonych za nas w ofierze na ołtarzu krzyża i uobecniających się podczas sprawowania Pamiątki Pana — jest

nowego życia i teraz działa On także przy uobecnianiu Paschalnego Ciała Chrystusa w Eucharystii.

${ }^{4}$ Por. np. Wj 26,30; 27,8 .

5 Por. A. Lod s, Les origines du sacrifice, „Revue d'Histoire et de la Philosophie Religieuse” 1(1921) s. 484 - 506, 483n; P. G r e lot, Présence de Dieu dans l'Ancien Testament, „Concilium” 40(1968) s. $11-21.13 .16$.

${ }^{6}$ Por. J. Drozd, Ostatnia Wieczerza Nowa Pascha, Katowice 1977, s. 27-30; Iz 43,16-21; Sof 3,18-20; Jr 16,14n; 1 Kor 5,7; 10,1-11; J 1,29; 10,10.

7 Por. W. S wi r rzaw s k i, Dynamiczna „Pamiątka Pana”, Kraków 1980, s. 23.110; J. B on s i v e n, Textes rabbiniques des deux premiers siècles chrétiens, Roma 1955, s. 215n (nr 868): „Rabbi Gamaliel mówił, że w każdym pokoleniu powinno się uważać, że to właśnie ono wyszło w Egiptu, wedlug Wj 13,8: „w tym dniu będziesz opowiadał synowi swemu: Dzieje się tak ze względu na to, co uczynił Jahwe dla mnie w czasie wyjścia z Egiptu" [...] dlatego trzeba wielbić [...] Tego, który dla nas i dla naszych ojców uczynil wszystkie te znaki [cuda]”. 
o wiele bardziej jasny i zrozumiały niż dla nas, żyjących obecnie i ukształtowanych przez inną kulturę.

Opis zawarcia Przymierza na Synaju zawiera także ważny element, do którego nawiążą potem autorzy opisów ustanowienia Eucharystii oraz natchniony twórca Listu do Hebrajczyków: „krew przymierza” — hebr. dam habb rît (Wj $24,6.8)$, którą skropiono ołtarz reprezentujący Boga oraz zgromadzony lud obydwu kontrahentów przymierza (Jahwe reprezentowany jest przez przedmioty przeznaczone dla Jego służby, szerzej wyliczone w Hbr 9,19-21). Krew ofiarnych zwierząt zapowiadała Krew Doskonałej Ofiary (por. Hbr 10,9n.14; 12,24) a Boże działanie poprzez Mojżesza, któremu duch Jahwe udzielał potrzebnych pouczeń w sprawach organizacji kultu, wskazuje na przyszłe działanie Ducha Świętego w Jezusie Chrystusie i w Kościele.

Przymierze synajskie okazało się jednak w dziejach Izraela niewystarczającym środkiem do uświęcenia ludu „o twardym karku” (por. Wj 32,9). Prorocy wielokrotnie zwracali uwagę, że nie wystarczy zewnętrznie wypełniać przepisy kultu i składać określone ofiary, ale trzeba poprzez uczciwe postępowanie wobec Boga i bliźniego pokazywać, że naprawdę chce się spełniać Jego wymagania i trwać w Jego Przymierzu ${ }^{8}$. Ponieważ dotychczasowe warunki nie zostały przez człowieka dochowane - okazało się, że nie jest on zdolny do wierności, Bóg zapowiada więc nowe, doskonalsze Przymierze, duchowe, przynoszące nadprzyrodzoną moc, która umożliwi zachowanie wymagań płynących z Bożej miłości. Jahwe umieści wówczas swe prawo w głębi jestestwa ludzi, wypisze je na ich sercach $(\mathrm{Jr} 31,33)$, da im jedno serce i jedną zasadę postępowania ( $\mathrm{Jr}$ $32,39)$, serce zdolne do poznania Boga (Jr 24,7). Będzie to przymierze wieczne (Jr 32,40): Bóg dokona wewnętrznej przemiany ludzkich serc - nastąpi jakby nowe stworzenie, dogłębne poznanie Boga umożliwiające wypełnienie Jego woli ${ }^{9}$.

Prorok Ezechiel zapowiada także Nowe Przymierze, w którym Bóg przemieni ludzkie wnętrza $(11,19-20$; por. 36,26$)$, da im swego Ducha, by żyli według Jego nakazów $(36,27)$ - Duch Boży będzie kształtował całe życie ludzi objętych tym nowym związkiem $\mathrm{z}$ Bogiem ${ }^{10}$. Inne teksty mówią o przyszłej szczęśliwości: obfitości dóbr potrzebnych człowiekowi do życia, udzielanych mu w tym nowym stanie przez działanie ducha Bożego ${ }^{11}$, zaproszeniu głodnych i spragnionych (Iz 55,1-3; por. Pnp 4,16-5,1), uczcie Mądrości (Prz 9,1

\footnotetext{
${ }^{8}$ Por. Oz 6,6; Prz 15,8; 21,3.27; Ps 40,7-9; 50,16 n; 69,31 n; Syr 34,17 n; 35,1-10; Dn 3,3840; Am 4,4 n; 5,22 n.25 n; Iz 1,10-20; Jr 7,22 n.

9 P. Volz, Der Prophet Jeremia, Leipzig 1922, s. 293 n; E. W. Nichols on, Jeremiah, Chapters 26-52, Cambridge 1975, s. 70 n; F. Nöt s ch e r, Jeremias, Würzburg 1947, s. 108.

${ }_{10}$ Por. Ez 16,60; 34, 25; 37, 15 - 28; Iz 32,15-20; J1 3,1 - 3 (wg LXX 2,28n.; cyt. w Dz 2,17 n).

11 Por. np. Iz 32,15-20; to dzialanie beedzie jakby nowym stworzeniem. Por. G. Foh re r, Das Buch Jesaja, Bd. 2, Zürich-Stuttgart 1967, s. 132; A. S. Herbert, The Book of the Prophet Isaiah 1-39, Cambridge 1973, s. 185; J. M a n chline, Isaiah 1-39, Confidence in God, London 1966, s. 217.
} 
-6; Syr 24,19-21) i nowej, czystej ofierze czasów mesjańskich, która zastąpi niedoskonały dotychczasowy kult $(\mathrm{Ml} 1,11)^{12}$.

Nowy pokarm z nieba zapowiadała również manna, którą Opatrzność Boża żywiła Izraelitów podczas wędrówki po pustyni (Wj 16, 14.31.35; por. $\mathrm{Mdr}$ $16,20)$. Ten niedoskonały „chleb z nieba” (Ps 78,24 $\mathrm{n}$ ) poprzedza prawdziwy pokarm i napój z nieba - Ciało i Krew Jezusa Chrystusa (por. J 6,31 35.48-58) złożone za nas w ofierze. Pieśni Sługi Jahwe występujące w drugiej części proroctwa Izajasza mówią o ofierze, jaką namaszczony Duchem Jahwe Boży Wybraniec $(42,1$ por. $11,1 \mathrm{n})$ złoży za grzeszników, przyjmując za nich dobrowolnie śmierć (por. Iz 53,4.8.12) ${ }^{13}$.

Te wszystkie zapowiedzi zostały zrealizowane, „kiedy nadeszła pełnia czasów” i „Bóg zesłał Syna swego, zrodzonego z niewiasty” (Ga 4,4), namaszczonego Duchem Swiętym, aby zaprowadził nowy kult, „w Duchu i prawdzie” (J 4,23). Sam Jezus Chrystus jest najściślej związany z Duchem Swiętym już od chwili poczęcia w łonie Matki (Łk 1,35; Mt 1,20). Ten przedziwny związek ukazuje się wyraźnie w ciągu całej Jego publiczności od chwili chrztu w Jordanie. Podając opis tego wydarzenia Ewangeliści akcentują bliską obecność Duchaosobowej Mocy Bożej ogarniającej Jezusa ${ }^{14}$, działającej podczas całego życia Nauczyciela z Nazaretu, głoszącego z mocą nową naukę (por. Mk 1,27) i potwierdzającego jej prawdziwość cudownymi znakami.

Całe życie Jezusa było najpełniejszym uwielbieniem Ojca — przykładem nowego kultu „w Duchu i prawdzie”, jakiego Ojciec wymaga od swoich czcicieli, ponieważ sam jest Duchem - Kimś zasadniczo różnym od człowieka $(\mathrm{J} 4,24)^{15}$. Jezus odchodząc do Ojca przekazal swoim uczniom Ducha Bożego, o którym mówił w okresie swego nauczania ${ }^{16}$. Scena Zesłania Ducha Swiętego przedstawiona jest w druigm rozdziale Dziejów Apostolskich jako wypełnienie proroctwa Joela o powszechnym wylaniu Ducha w czasach mesjańskich (J1 3,1-5 cyt. w mowie św. Piotra - Dz 2,17-21). Odtąd życie Kościoła i sprawowany przezeń kult podporządkowane są działaniu Ducha Swiętego, który jest źródłem apostolskiej gorliwości, przez cudowne znaki potwierdza nauczanie Apostołów (por. Dz 2,4.6.11; 3,7; 5,12.15), dodaje odwagi w zno-

12 Por. J. Kodell, Lamentations, Haggai, Zachariah, Malachi, Obadiah, Joel, Second Zachariah, Baruch, Wilmington-Delaware 1982, s. 99 n.

${ }_{13}$ Por. L. Ne ve, The Spirit of God in the Old Testament, Tokyo 1972, s. 76; J. H. Sch e epe r s, Die Goes van God en die Goes van die mens in die Oud Testament, Amsterdam 1960, s. 166 -167 .

${ }^{14}$ Mk 1,9-11; Mt 3,13-17; Łk 3,21 n; J 1,32 nn; por. M. -J. Lag ra n ge, Evangile selon Saint Matthieu, Paris 1948, s. 55; W. Trillin g, Das Evangelium nach Matthaeus, Leipzig 1962, s. $65 \mathrm{n} ;$ A. Jankowski, Duch Odnowiciel. Szczególny aspekt eschatologicznego postannictwa Ducha Swiętego, „Analecta Cracoviensia” 4(1972) s. 125 - 145 (129).

${ }^{15}$ Duch w sensie biblijnym oznacza rzeczywistość Boską, przekraczającą każdy inny byt; $\mathrm{H}$. van den Bus s ch e, Jean, Bruges 1967, s. 193. Podobny sens ma Pawłowe sformułowanie: „Pan zaś jest Duchem” (2 Kor 3,17); por. R. Rubinkiewicz, „Pan zaś jest Duchem” (2 Kor 3,17), „Ruch Biblijny i Liturgiczny” 35 (1982), s. 36-42 (41n.).

${ }^{16}$ Por. np. Łk 11,13; J 3,34; 7,39; 14,17.26; 15,26; 16,13. 
szeniu prześladowań $(\mathrm{Dz} 4,13.31 ; 5,10 ; 10,10)$, działa w sercach poszczególnych wiernych ucząc ich synowskiej modlitwy ( $\mathrm{Rz} 8,15$ n. 26) i kontynuuje dzieło Jezusa Chrystusa głoszącego Królestwo Boże ${ }^{17}$.

Duch Święty jest także Duchem Prawdy (J 15,26; 16,13). Wyrażenia odnoszące się do prawdy (gr. alēthēia, a zwłaszcza alēthēs i alēthinós) występują w pismach Janowych znacznie częściej niż w pozostałych tekstach Nowego Testamentu: Prawdą nazwany jest sam Jezus (J 14,6), mówi się o Duchu prawdy $(15,26 ; 16,13)$, kulcie w Duchu i w prawdzie $(4,23 \mathrm{n})$ i o prawdziwych czcicielach $(4,23)$. Wszystko to składa się na nową rzeczywistość, stanowiącą wypełnienie prawdziwych zapowiedzi proroków, naprawdę powołanych przez Boga i obdarzonych Jego Duchem Prawdy. Można powiedzieć, że Duch Swięty jest Tym, który ciągle jest obecny na kolejnych etapach zbawczego planu Boga i gwarantuje ciągłość Jego prawdy.

Chrześcijański kult w Duchu i prawdzie polega na trwaniu w prawdziwej wierze, wypełnianiu płynących z niej nakazów miłości Boga nade wszystko i bliźniego na wzór Chrystusa, który oddał swoje życie za przyjaciół (por. $\mathrm{J} 15,12 \mathrm{n} ; 13,1.34 \mathrm{n}$ ), oraz na trwaniu w modlitewnej jedności z Panem, za przykładem samego Jezusa, który wiele i często się modlił (por. np. Łk 5,16; 6,12; $9,18 ; 11,1)$. Sw. Paweł w Liście do Filipian nazywa kultem w Duchu Bożym całe nowe życie chrześcijan w przeciwieństwie do dawnego: „my bowiem jesteśmy prawdziwym ludem obrzezanym — my, którzy sprawujemy kult w Duchu Bożym i chlubimy się w Chrystusie Jezusie, a nie pokładamy ufności w ciele" $(3,3)$. Greckie wyrażenie hoi pneúmati theoũ latreúontes oznacza dokładnie — „sprawujący kult Duchem Boga - przez Ducha Bożego” — dzięki Jego mocy, na co wskazuje dativus instrumentalis, jak w Rz 8,14 i Ga 5,5.18 ${ }^{18}$. Brak rodzajnika nie może tu przeszkadzać w uznaniu Ducha za Trzecią Osobę Trójcy Przenajświętszej ${ }^{19}$, której działanie przemienia osobę ludzką w jej najgłębszym wnętrzu ${ }^{20}$, w przeciwieństwie do tego wszystkiego, co oznacza pokładanie ufności w ciele ${ }^{21}$. Termin oznaczający sprawowanie kultu - latreúein ma w Septuagincie znaczenie wyraźnie odnoszące się do liturgii, która w nowej sytuacji nie ma być sprawowana tylko w Jerozolimie, ale wszędzie tam, gdzie działa Duch skierowujący wszystko ku Bogu ${ }^{22}$. Nowy kult nie jest zewnętrzną

17 Por. np. Dz 5,32; 15,28 .

${ }^{18}$ Por. H. R. Vin ce n t, Critical and Exegetical Commentary on the Epistles to the Philippians and to Philemon, Edindburh 1902, s. 93.

19 A. J a n k ow ski, Listy więzienne, Poznań 1962, s. 142.

${ }^{20}$ Por. G. F. Haw th or n e, Philippians, Waco-Texas 1983, s. 127; J. J. Mülle r, The Epistles of Paul to the Philippians and to Philemon, Grands Rapids-Michigan 1955, s. $107 \mathrm{n}$.

21 Por. G. Friedrich, Der Brief an die Philipper, [w:] J. Becher, H. Conzelmann, G. Fried ri ch, Die Briefe an die Galater, Epheser, Philipper, Kolosser, Thessalonicher und Philemon, Göttingen 1976, s. 125 - 175. 159; A. J a n k ow s ki, Listy..., s. 142.

${ }_{22}$ Por. R. P. Martin, The Epistle of Paul to the Philippians, London 1967, s. 139; F. W. B ea re, A Commentary on the Epistle to the Philippians, London 1969, s. 105; G. B a r t h, Der Brief an die Philipper, Zürich 1979, s. 56; J. H. Mich a el, The Epistle of Paul to the Philippians, London 1948 , s. $137 \mathrm{n}$. 
ceremonią, lecz dziełem Boga, który sam uczy swój lud, w jaki sposób należy Go wielbić23. Zupełna nowość polega na wszczepieniu w nową rzeczywistość, przyniesioną przez Jezusa Chrystusa, która ma teraz trwać i działać, przynosząc Bogu doskonałą chwałę.

Święty Paweł wielokrotnie przeciwstawia tę dynamiczną nowość dawnemu stanowi, którego symbolem jest litera Prawa Dawnego Przymierza a wymownym przykładem sposób postępowania faryzeuszów, którzy w wierności zewnętrznym przepisom upatrywali drogę do zbawienia, usprawiedliwienia, czyli uznania ich przez Boga za sprawiedliwych. Ewangelie podają wiele przykładów krytycznego odniesienia Jezusa do faryzeuszów (np. Mt 23,1 - 38; por. Mk 12,38 nn; Łk 20,45-47; Mk 8,14-21 par.; Łk 11,37-52;16,14 n); przeciwstawia On swoją naukę ich nauczaniu, co szczególnie jasno przedstawione jest w Mateuszowym opracowaniu Kazania na Górze, gdzie tradycyjnej interpretacji przykazań Dekalogu cytowanych z formułą wprowadzającą „Słyszeliście, że powiedziano (przodkom)" (Mt 5,21.27.31.33.38.43) Jezus przeciwstawia własną naukę o miłości umożliwiającej doskonałe wypełnienie tych przykazań: „A Ja wam powiadam” (5,22.28.32.34.39.44). Jezus w Duchu Swiętym ukazuje właściwe rozumienie litery Prawa. Kto zatrzymuje się na literze, nie jest w stanie zrozumieć Jego nauki i osiągnąć Królestwa Bożego. „Jeśli wasza sprawiedliwość nie będzie większa niż uczonych w Piśmie i faryzeuszów, nie wejdziecie do królestwa niebieskiego" (Mt 5,20).

Apostoł Narodów, dawny faryzeusz (Flp 3,5; Dz 23,6) dobrze zrozumiał tę nowość, w którą zostajemy włączeni przez chrzest, zanurzający nas w śmierć razem z Chrystusem, aby wraz z Nim powstać do nowego życia (por. Rz 6,4) ${ }^{24}$. To nowe życie jest życiem według prawa Ducha, który daje życie w Chrystusie Jezusie, ono wyzwoliło nas spod prawa grzechu i śmierci $(\mathrm{Rz} 8,2)$. Określenie chrztu z listu do Tytusa ukazuje ten sakrament jako „obmycie odradzające i odnawiające w Duchu Świętym" $(3,5)$ - początek nowego życia w Duchu, wewnętrzną przemianę będącą antytypem tego, co zapowiadały proroctwa Starego Testamentu o nowym stworzeniu. Obecność Ducha charakteryzuje bytowanie chrześcijan w czasie, jaki im Bóg daje ${ }^{25}$. Odpowiedzią człowieka na ten wielki dar jest całkowite oddanie się na służbę Bożą (por. Rz 6,13), wydawanie „owoców Ducha”, którymi są „miłość, radość, pokój, cierpliwość, uprzejmość, dobroć, wierność, łagodność, opanowanie" (Ga 5,22 n): cnoty będące $\mathrm{z}$ jednej strony darem Boga, $\mathrm{z}$ drugiej zadaniem by praktykować je niekiedy $\mathrm{z}$ wielkim wysiłkiem, przeciwstawiając się skłonnościom natury osłabionej po grzechu Adama (por. $\mathrm{Rz} 7,14-25$ ).

${ }^{23}$ Por. P. Bonn ard, L'épître de Saint Paul aux Philippien, [w:] P. B on ard, L'épître de Saint Paul aux Philippien, Ch. M a s so n, L'épître de Saint Paul aux Colossiens, Neuchâtel-Paris 1950 , s. $7-82(61)$.

${ }_{24}^{4}$ Por. H. Schlier, Der Römerbrief, Freiburg-Basel-Wien 1977, s. 193.

${ }^{25}$ Por. H. H. Sch a de, Apokalyptische Christologie bei Paulus, Göttingen 1981, s. 153 (55). 
Życie „duchowe” chrześcijan, przeciwne dawnemu, „cielesnemu” postępowaniu, to wynik obecności w sercach ochrzczonych Ducha Świętego, którego Zmartwychwstały Chrystus - zgodnie z wcześniejszymi obietnicami (por. J 14 - 17), posłał swemu Kościołowi stanowiącemu Jego Ciało (por. np. Rz 12,5; 1 Kor 6,12 - 20; Ef 1,22 n; 4,4; Kol 1,24; 3,10.15), świętą społeczność, kontynuującą dzięki mocy Ducha Świętego dzieło, jakie On rozpoczął w czasie swego ziemskiego życia. Duch Święty sprawia, że wierni głębiej rozumieją Chrystusową naukę i płynące z niej wymagania, dobrowolnie poddają się swemu Stwórcy i odkupicielowi, łącząc w jedno obrzędy kultu z całym swoim życiem $^{26}$. Kościół - Chrystus eklezjalny - kontynuuje to, co wynika z dokonanego raz na zawsze zbawczego dzieła Jezusa Chrystusa, stanowiącego wypełnienie zapowiedzi Starego Przymierza, doskonały akt kultu na chwałę Ojcu oraz inaugurację nowego kultu, który w tej postaci ma być sprawowany aż do powtórnego przyjścia Pana w chwale.

OFIARA NOWEGO PRZYMIERZA:

CHRYSTUS ARCYKAPEANEM ZA SPRAWĄ DUCHA SWIĘTEGO

Rozpatrując związek Eucharystii z Duchem Świętym, rozważyliśmy przygotowanie więzi Ofiary Nowego Przymierza z Duchem Jahwe w Starym Testamencie i realizację zapowiedzi poprzez życie i działalność Jezusa Chrystusa związanego najściślej z Duchem od momentu poczęcia w łonie Matki. Więź ziemskiego Jezusa z Duchem Świętym jest kontynuowana przez obecność Ducha w Kościele - świętej społeczności, która jest Ciałem Chrystusa oraz w każdym członku Kościoła - człowieku, który przez chrzest został włączony w zbawcze dzieło Jezusa Chrystusa. Obecnie dokładniej przyjrzymy się tekstom mówiącym o Jezusie Chrystusie jako Arcykapłanie za sprawą Ducha.

Spośród pism Nowego Testamentu najwięcej o kapłaństwie Chrystusa mówi List do Hebrajczyków. Tylko tam Jezus jest wprost nazwany arcykapłanem (po raz pierwszy w 2,17) lub kapłanem. Jednakże to, co zawiera się w treści tytułu kapłana — pośrednika między Bogiem i ludźmi, zawarte jest także w innych tekstach. Wiele $\mathrm{z}$ nich koncentruje się głównie na ofierze Jezusa, ale można powiedzieć, że to, co Nowy Testament mówi o zbawczej misji Wcielonego Syna Bożego, którego Bóg posłał na świat, by spełnił wobec niego misję kapłańską, znajduje swe podsumowanie w tytułach przyznawanych Jezusowi przez natchnionego autora Listu do Hebrajczyków ${ }^{27}$. W tekście tym dwukrot-

${ }^{26}$ Por. F. Me negoz, L'Esprit de l'Eglise, „Revue d'Histoire et de la Philosophie Religieuse” $22(1942)$ s. $106-131(125)$.

27 Nauka NT o kapłaństwie Chrystusa różni się zasadniczo od judaistycznych koncepcji kapłańskiego Mesjasza, reprezentowanych m.in. przez teksty odnalezione w Qumran; - por. A. J. B. Higgins, The Priestly Messiah, NTS $13(1966-67)$ s. $211-239(234$ n); A. Ja nk ow s ki, K. Rom a ni u k, Kaptaństwo w Piśmie Świętym Nowego Testamentu, Katowice 1972, s. 55. 
nie ofiara lub kapłaństwo Chrystusa zostały połączone z rzeczywistościami duchowymi przy użyciu terminów wskazujących na działanie Ducha: [inny kapłan], „który stał się takim nie według przepisu prawa cielesnego, ale według siły niezniszczalnego życia" $(7,16)$. Przeciwstawienie zawarte w tym wierszu jest analogiczne do Pawłowego kontrastu między rzeczywistościami cielesnymi i duchowymi. Kapłaństwo Chrystusa różni się zasadniczo od dawnego, zewnętrznego porządku. Jest podstawowym elementem nowej rzeczywistości kształtowanej przez Ducha Świętego, Dawcę życia.

Po raz drugi określenie wskazujące na działanie Ducha Świętego znajdujemy w Hbr 9,14: „o ileż bardziej krew Chrystusa, który przez Ducha wiecznego złożył Bogu samego siebie jako nieskalaną ofiarę, oczyści wasze sumienia z martwych uczynków, abyście mogli służyć Bogu żywemu". W poprzednim wierszu autor odwołuje się do obrzędów oczyszczenia ze Starego Testamentu i ich rytualnej skuteczności w dawnym, cielesnym porządku. Ofiara Chrystusa została złożona Bogu przez Ducha wiecznego. Wydaje się, że tu związek z Duchem odnosi się przede wszystkim do wniebowstąpienia Chrystusa Arcykapłana, wchodzącego do wiekuistego sanktuarium nieba, by tam Ojcu przedstawić złożoną raz na krzyżu ofiarę. Chrystus wchodzi do nieba w chwale i mocy „życia niezniszczalnego" zapewnionej Mu przez Ducha Świętego ${ }^{28}$. Można jednak działanie Ducha odnieść i do samego aktu ofiary ${ }^{29}$.

Hbr 9,14 zawiera także parę sformułowań, które przeciwstawiają dawny i nowy porządek, zwracając szczególną uwagę na ich związek ze śmiercią lub życiem: „Duch wieczny” wskazuje na eschatologiczne ukierunkowanie Bożego działania przez Ducha ${ }^{30}$. Można też „wiecznego Ducha” przeciwstawić „przepisom tyczącym się ciała, nałożonym do czasu naprawy” $(9,10)$. „Martwe uczynki" zanieczyszczające sumienia wiernych, to dawny sposób postępowania. Teraz krew Chrystusa oczyściła raz na zawsze $(7,27)$ serca wiernych, to znaczy dała siłę do przezwyciążenia skutków grzechu, lecz nie zwolniła oczyszczonych z gorliwej troski o praktykowanie miłości, przeciwstawianie się złu i znoczenie prześladowań za przykładem świętych Starego Testamentu, o czym mówi druga, parenetyczna część Listu (rozdz. 10-13).

Mówiąc o kapłaństwie Chrystusa różnym od kapłaństwa lewickiego natchniony autor Listu do Hebrajczyków kilkakrotnie nawiązuje do mesjańskie-

${ }^{28}$ A. J a n kowski, „Przez Ducha wiecznego” (Hbr 9,14). Próba uściślenia sensu pneumatologicznego tego zwrotu, „Analecta Cracoviensia” 3(1971) s. $201-220$ (219).

${ }^{29} \mathrm{~A}$. V a n h oy e zestawia ten tekst z Kpł 6,5 - 6 o wiecznym ogniu na ołtarzu przybytku ST i porównuje ogień spadający od Boga, który pochłania ofiary, z działaniem Ducha Świętego w ofierze Chrystusa; por. Esprit éternel et feu du sacrifice en he 9,14, „Biblica” 64 (1983) s. $263-274$ (274).

${ }^{30}$ Niektórzy odnoszą określenie „Duch wieczny” do duszy lub do wiecznej natury Chrystusa; por. H. Montefiore, The Epistle to the Hebrews, London 1969, s. 154 n; A. Jank owski, „Przez Ducha wiecznego"..., s. 204 - 207. My odnosimy to określenie do Ducha Świętego zawsze obecnego w Bożym działaniu zbawczym. Wieczny Duch powoduje też, że skutki ofiary Chrystusa, przez Ducha złożonej, są trwałe i duchowe; por. T. J el o n e k, Rola Ducha Świętego wedtug Listu do Hebrajczyków, „Ruch Biblijny i Liturgiczny” 34 (1981) s. 119 - 129 (124). 
go Psalmu 110, który w wierszu 4 zapowiada, że przyszły pomazaniec będzie równocześnie królem i kapłanem na wieki na wzór Melchizedeka. Imię Melchizedeka występuje w Hbr 11 razy, z tego w 6 wypadkach w cytacie lub aluzji do Ps 110,4. W Rdz 14,17 - 20 pojawia się tajemniczy pogański król — kapłan Boga Najwyższego ('El 'Eljôn), który błogosławi Abrahama po zwycięstwie odniesionym nad królami mezopotamskimi i otrzymuje od niego dziesięcinę. Rdz 14,17 mówi, że „Melchizedek król Szalemu wyniósł (hebr. hôsî’) chleb i wino", co można tłumaczyć jako podanie posiłku żołnierzom zmęczonym walką i pościgiem ${ }^{31}$. Jednocześnie trzeba wziąć pod uwagę, że te obydwa najbardziej podstawowe składniki ludzkiego pożywienia zostały użyte przez Chrystusa jako zewnętrzne postaci Sakramentu Jego Ciała i Krwi, podawane jako pokarm i napój tym, którzy w Niego uwierzą i będą trwać w Jego Kościele, zjednoczeni w jedności Ducha, którego On pośle do Ojca (por. J 15,26).

Chrystus jest kapłanem na wieki na wzór Melchizedeka nie tylko dlatego, że nie pochodzi z pokolenia Lewiego (por. Hbr rozdz. 7), ale też — jak mówi Tradycja - dlatego, że posłużył się tymi samymi materialnymi elementami, które wyniósł w związku ze spotkaniem z Abrahamem Melchizedek ${ }^{32}$. Bez względu na historyczną wartość Rdz 14,17 - 20 $0^{33}$ midrasz z Hbr 7 wskazuje na teologiczne znaczenie tego tekstu jako pochodzącej od Ducha Świętego zapowiedzi nowego, doskonalszego kapłaństwa, wolnego od ograniczeń, którym podlegało kapłaństwo lewickie i zarazem zapowiedzi nowej ofiary - bardzo różniącej się od cenionych szczególnie w starożytności krwawych, całopalnych ofiar ze zwierząt.

Zbliżanie się ludzi do Boga dokonuje się stopniowo. Centralnym momentem tego procesu w obecnym porządku zbawienia była ofiara Syna Bożego (Hbr 9,11 n). Zakończy się on dopiero $\mathrm{z}$ chwilą Jego powtórnego przyjścia w chwale (Mt 25,31 Hbr 9,26-28).

Wprowadzenie Prawa dawnego i nowego wiąże się z Bożą obietnicą — uroczystym oświadczeniem, które Bóg złożył Noemu (Rdz 8,20 - 9,17), Abrahamowi (Rdz 12,1 - 3; 17,1 - 8) i wobec Mojżesza na Synaju (Wj rozdz. 24) analogicznym do przysięgi, o której mówi Ps 110,4 , cytowany w Hbr 7,21. Poszczególni ludzcy arcykapłani Izraela wchodzili na swój urząd bez składania przysięgi $(\mathrm{Hbr} 7,19)$. Wyjątkowa sytuacja kapłaństwa Chrystusa polega na tym, że sam Bóg przysiągł właśnie Jemu, że zostanie ustanowiony kapłanem na wieki. Trudno w ludzki sposób wytłumaczyć obecność takiego sformułowania

31 Por. J. S. Fitzm y e r, „Now this Melchizedek...” (Heb 7,1), CBQ 25 (1963) s. $305-321$ (315). Teologiczne znaczenie spotkania Abrahama z Melchizedekiem jest bezsporne bez względu na to, jakie stanowisko przyjmuje się co do historycznej wartości epizodu por. M. P e te r, Rzeczywistość historyczna w Rdz 14, „Ruch Biblijny Liturgiczny” 29 (1976) s. 10-19.17-19.

32 Tradycyjnie tłumaczy się działanie Melchizedeka jako ofiarę złożoną Bogu; por. A. V a cca ri, „Melchisedec, rex Salem, proferens panem et vinum”, VD 18 (1938) s. 208 - 214 (235 243), 243.

${ }^{33}$ Por. M. Peter, Rzeczywistość historyczna..., s. $17-19$. 
— odbiegającego od przyjętych w Izraelu sposobów myślenia, w mesjańskim Psalmie 110. Dopiero pełnia Objawienia ukazuje cały jego sens.

W ostatnich wierszach rozdziału siódmego Listu do Hebrajczyków mamy doskonałą charakterystykę naszego Arcykapłana: „ponieważ trwa na wieki, ma kapłaństwo nieprzemijające. Przeto i zbawiać na wieki może całkowicie tych, którzy przez Niego zbliżają się do Boga, bo zawsze żyje, aby się wstawiać za nimi” (w. 24 n). Tekst nie mówi wprost o Duchu Świętym, lecz wiemy, że wieczne życie Zmartwychwstałego Pana oraz ducha łączność Jego z wiernymi — wstawiennictwo - wiąże się ściśle z osobą i działaniem Ducha, który u św. Pawła wstawia się za wierzącymi w błaganiach niewyrażalnych słowami, uzupełnia ich modlitwę i jednoczy ich z Trójcą Przenajświętszą (por. Rz 8,26). Warto też przytoczyć tu dla porównania inny tekst o pośrednictwie zbawczym Chrystusa: „Albowiem jeden jest Bóg, jeden też pośrednik między Bogiem a ludźmi, człowiek, Chrystus Jezus, który wydał siebie samego na okup za wszystkich jako świadectwo we właściwym czasie" (1 Tm 2,5-6). Mówi się tu o pośrednictwie, ofierze i świadectwie. Nie ma wprost wzmianki o Duchu Świętym, ale zwłaszcza czynność świadczenia — dawania świadectwa można zestawić $\mathrm{z}$ funkcją Parakleta z J 15,26 stanowiącą kontynuację świadectwa Pośredni$\mathrm{ka}$, ale też ściśle związaną z funkcją samego Pośrednika napełnionego Bożym Duchem ${ }^{34}$.

W Hbr 7,26 n mamy wyliczone cechy arcykapłana ,jakiego nam było potrzeba - święty, niewinny, nieskalany, oddzielony od grzeszników, wywyższony ponad niebiosa, nie zobowiązany (jak inni) do składania codziennej ofiary najpierw za swoje grzechy, a potem za grzechy ludu". Chrystus był do nas podobny we wszystkim, $\mathrm{z}$ wyjątkiem grzechu (por. 4,15 ). Tu podkreślono cechy różniące Go od ludzkich arcykapłanów - cechy, które posiadał jako wcielony Syn Boży — święty — bez jakiejkolwiek niedoskonałości moralnej, stojący bardzo blisko Boga. Oddzielony od grzeszników - ale nie oddzielony od ludzi, od których różnił się pod względem doskonałości, ale dobrowolnie przyjął na siebie ich ograniczenia ${ }^{35}$.

Pośrednik musi stać blisko obydwu stron, między którymi pośredniczy. Chrystus posiadał prawdziwą ludzką naturę, był jednym z nas, ludzi. Teraz podziwiamy Jego wyniesienie, związek z Bogiem. Wyniesienie ponad niebiosa nastąpiło po podjęciu i dokonaniu Męki - przyjęciu całej ludzkiej słabości. Dokonało się to raz na zawsze i nie ma potrzeby składania innej ofiary na przebłaganie Bożego majestatu: Chrystus nigdy nie musiał błagać o odpuszczenie własnych grzechów, ale Jego - świętego, niewinnego, nieskalanego, oddzielonego od grzeszników (Hbr 7, 26) „Bóg dla nas uczynił grzechem” (por. 2 Kor

${ }^{34}$ Por. G. Holt z, Die Pastoralbriefe, Berlin 1965, s. 60 n; C. K. B a r r e t t, The Gospel according to St. John, London 1967, s. 402.

${ }_{35}$ Por. S. Ła ch, List do Hebrajczyków, Poznań 1959, s. 200 n. 
5,21; Ga 3,13) - kazał Mu podjąć całe przekleństwo, jako następstwo grzechu, by wyzwolić z tego przekleństwa ludzi.

„Prawo ustanawiało arcykapłanami ludzi obciążonych słabością, słowo zaś przysięgi, złożonej po nadaniu Prawa, (ustanawia) Syna doskonałego na wieki” (Hbr 7,28). Boża przysięga — to również szczególny sposób zwracania się Boga do człowieka, dziedzina, w której specjalną rolę odgrywa Duch Swięty. Cały porządek dawnego prawa dostosowany był do ludzkiej słabości, wiązał się z cielesnymi ograniczeniami. Nowy porządek Ducha jest od nich wolny: Syn - Arcykapłan - Pośrednik jest nieskończenie doskonały i Jego kapłaństwo zostało Mu dane raz na zawsze - trwa wiecznie, jak On sam jest wieczny i wieczne są plany Bożej miłości ${ }^{36}$.

Nie ma potrzeby powtarzania ofiary Chrystusa, by zadośćuczynić za coraz to nowe ludzkie grzechy: Bóg nie podlega czasowym ograniczeniom. Raz złożona fiara gładzi wszystkie winy. Natomiast ludzka słabość potrzebuje pamiątki zbawczej ofiary dokonanej przez Jedynego Arcykapłana i dlatego On nam tę pamiątkę ustanowił. Zesłał nam również samego Ducha, byśmy trwali w Nim i odnawiali się ciągle, czerpiąc ze zdroju łaski i zwyciężając codziennie naszą słabość dzięki Jego mocy.

W ósmym rozdziale $\mathrm{Hbr}$ natchniony autor cytuje $\mathrm{Jr} 31,31-34$ (w. 8-12) głosząc wypełnienie proroczej zapowiedzi, nastanie nowego, duchowego przymierza przez zbawczy czyn Arcykapłana, który ,zasiadł po prawicy tronu Majestatu w niebiosach jako sługa świątyni i prawdziwego przybytku zbudowanego przez Pana, a nie przez człowieka" (Hbr 8,1 n). Dawny kult był tylko niedoskonałą zapowiedzią, obrazem i cieniem (w. 5) tego, co teraz nastąpiło, a co jest udostępnieniem ludziom rzeczywistości niebieskich ${ }^{37}$.

„Krew Chrystusa, który przez Ducha wiecznego złożył Bogu samego siebie jako nieskalaną ofiarę, oczyści wasze sumienia z martwych uczynków, abyście służyć mogli Bogu żywemu" (Hbr 9, 14) — o wiele bardziej skutecznie, niż starotestamentowe obrzędy przynosiły rytualne oczyszczenie — por. w. 13. „I dlatego jest pośrednikiem Nowego Przymierza, ażeby przez śmierć, poniesioną dla odkupienia przestępstw, popełnionych za pierwszego przymierza, ci, którzy są wezwani do wiecznego dziedzictwa, dostąpili spełnienia obietnicy" (w. 15). Jego śmierć jest najważniejszym momentem Nowego Przymierza nie tylko jako spełnienie prawnego warunku ludzkiego testamentu, który nabiera mocy po śmierci testatora (w. $16 \mathrm{n}$ ), lecz jako odkupienie nas z grzechów Jego własną krwią - podobnie jak krew cielców i kozłów służyła do pokropie-

${ }^{36}$ Por. H. Montefiore, The Epistle to the Hebrews..., s. 131.

${ }^{37}$ Por. L. S a bou ri n, „Liturgie du Sanctuaire et de la Tente Véritable” (Héb. VIII 2), NTS 18 $(1971$ - 72) s. 87 - 90 (90); S. Ła ch, jw. s. 206 n; C. S p i cq, L'Epître aux Hebreux, II: Commentaire, Paris 1953, s. 236. 
nia tego, co służyło ludziom do oddawania czci Bogu oraz samego ludu w Starym Przymierzu ${ }^{38}$ (por. w. $18-22$ ).

Obok tekstów z Listu do Hebrajczyków mówiących o kapłaństwie i zbawczej ofierze Jezusa Chrystusa warto jeszcze przytoczyć kilka tekstów Pawłowych wyrażających te same prawdy w nieco inny sposób. W Rz 3,25 Apostoł Narodów mówiąc o nowej sprawiedliwości przez wiarę w Jezusa Chrystusa stosuje do Niego znamienne określenie wywodzące się ze Starego Testamentu: „Jego to ustanowił Bóg narzędziem przebłagania przez wiarę mocą Jego krwi”. Grecki tẹmin hilastērion oddaje w Septuagincie hebr. kappōret oznaczające przebłagalnię - pokrywę Arki Przymierza, nad którą raz w roku arcykapłan dokonywał obrzędu przebłagania (Kpł 16,14 n). List do Hebrajczyków nawiązuje do tych zwyczajów bez odwołania się jednak do konkretnego, materialnego przedmiotu i jego nazwy oraz znaczenia — prawdopodobnie dlatego, że po powrocie z niewoli w odbudowanej świątyni nie było już nowej Arki Przymierza, ukrytej według tradycji w nieznanym miejscu przez proroka Jeremiasza (por. 2 Mch 2,5). Przebłagalnią jest teraz ciało Jezusa - poczęte mocą Ducha Swiętego (Łk 1,35; Mt 1,18.20) i zarazem cała Jego osobowość, najściślej zjednoczona z Duchem Bożym, którego działanie przejawiało się nieustannie podczas całej Jego działalności. Dawna przebłagalnia - podnóżek tronu Bożego (por. Ps 99,5; 132,7; 1 Krn 28,2) — była skrapiana krwią ofiary zastępującej arcykapłana i cały naród. Przed jej zabiciem arcykapłan kładł ręce na jej głowie, niejako symbolicznie składając na niej wszystkie przewinienia własne i ludu (por. Kpł 4,4.15 - rozdz. $16 \mathrm{Kpł} \mathrm{opisujący} \mathrm{obrzędy} \mathrm{Dnia} \mathrm{Przebłagania} \mathrm{nie}$ mówi wprost o wkładaniu rąk na głowę kozła, ale ogólnie określa go jako ofiarę przebłagalną - 16, 9.15-zaś do ofiar przebłagalnych stosowano przepisy z Kpł 4, gdzie włożenie rąk stanowiło ważny znak przeniesienia grzechów winowajców na zwierzę ofiarne).

Jezus Chrystus także uobecniał Boga - Bóg na Nim spoczywał, jak spoczywał według Starego Testamentu na Arce — podnóżku Jego stóp - i przemawiał stamtąd do Mojżesza (por. Wj 25,22). Teraz Jezus jest jednocześnie miejscem i ofiarą. Jego Krew została przez Niego samego wniesiona do Bożej świątyni jako objaw najwyższej czci i najskuteczniejszego przebłagania oraz zadośćuczynienia za występki wielu (por. Hbr 9,12.28).

Jako skutek tego faktu nastąpiło wyrównanie sprawiedliwości w stosunkach między Bogiem a ludźmi — raz na zawsze skuteczne przebłaganie za ludzkie grzechy i zmiana środków umożliwiających ludziom dążenie do doskonałości: zamiast wypełniania przykazań Prawa Starego Testamentu warunkiem zbawienia jest obecnie wiara w Jezusa Chrystusa, w Jego zbawcze dzieło.

On sam jest narzędziem przebłagania. Został nim ustanowiony przez Boga mocą Jego krwi. Krew to rzeczywistość ofiary Jezusa Chrystusa: choć Apostoł

${ }^{38}$ Krew pełni uprzywilejowaną rolę w pośrednictwie zadośćuczynienia wobec Najświętszego Boga; por. C. Pa ty, Dieu Saint, Peuple Saint, BiVieChret 36 (1960) s. 41 - 53 (47 n). 
nie używa terminu „ofiara”, wskazuje na nią Krew Zbawiciela - Krew Nowego Przymierza (por. 1 Kor 11,25; Łk 22,20; Mk 14,24; Mt 26,28) ${ }^{39}$.

W Rz 5,9 św. Paweł pisze: Tym bardziej więc będziemy przez niego zachowani od karzącego gniewu, gdy teraz przez krew Jego zostaliśmy usprawiedliwieni”. Chrystus zachowuje nas od karzącego gniewu Bożego jako Ten, który dokonał za nas obrzędu przebłagania - miłego Bogu i skutecznego raz na zawsze.

Mamy przez Chrystusa - przez wiarę i udział w Jego zbawczym dziele, zachowywać pokój z Bogiem (por. 5,1), gdyż dzięki Niemu przez wiarę uzyskaliśmy dostęp do łaski, w której trwamy i chlubimy się nadzieją chwały Bożej (w. 2). Trwanie w wierze to także znoszenie ucisków dla sprawy Bożej (por. w. 3): nie jest to tylko sama wiara bez uczynków. Dane uczynki polegające na wypełnianiu Prawa zastąpiła wytrwałość w zewnętrznych prześladowaniach i wytrwałość w pełnieniu woli Bożej. Obejmuje ona też wytrwałość w wewnętrznych uciskach - utrapieniach powodowanych przez dawnego człowieka grzeszną pożądliwość, stare nałogi, oraz wytrwałość w utrapieniach wywolywanych przez szatana, przeciwnika Boga i ludzi, który chce wykorzystać naszą słabość i odciągnąć nas od łaski.

Ucisk wyrabia wytrwałość, wytrwałość - wypróbowaną cnotę, wypróbowana cnota zaś - nadzieję (w. 3-4). „A nadzieja zawieść nie może, ponieważ miłość Boża rozlana jest w sercach naszych przez Ducha Świętego, który został nam dany" $(5,5)$. Mamy łańcuch, w którym jedno ogniwo jest źródłem następnego: ucisk - wytrwałość — wypróbowana cnota — nadzieja — miłość Boża - i na końcu Duch Swięty.

Ucisk to przede wszystkim prześladowania, ale może też wewnętrzne trudności. Prawdopodobnie ta druga możliwość nie rysowała się wyraźnie pierwszym uczniom Apostoła Narodów, dla których prawdopodobieństwo męczeńskiej śmierci było bardzo duże ${ }^{40}$, ale chyba i oni znali inne uciski — od fałszywych braci, lecz również i ze strony ościenia ciała, wysłannika szatana (por. 2 Kor 12,7). Trzeba je znosić, gdyż laska Boża wystarczy do przezwyciężenia wszystkiego, a znoszenie tych przeciwności wyrabia wytrwałość, zaś wytrwałość - wypróbowaną cnotę, czyli sprawność, łatwość w pełnieniu dobrych czynów, zwyciężaniu własnej słabości, okazywaniu Bogu wierności wtedy, gdy to jest trudne i wymaga wysiłku. Sam Chrystus zjednoczony z Duchem Swiętym jest doskonałym przykładem znoszenia przeciwności aż do całkowitej ofiary $z$ siebie. Ta ofiara jest źródłem mocy dla Jego wyznawców - do naśladowania swego Mistrza i Pana.

Nadzieja w Liście do Hebrajczyków opierała się na ofierze Chrystusa Arcykapłana Nowego Przymierza (por. Hbr 6,18 n; 7,19; 10,23). W Rz 5,5 „nie może zawieść", gdyż miłość Boża rozlana jest w naszych sercach przez Ducha,

${ }^{39}$ Por. C. K. B arrett, A Commentary on the Epistle to the Romans, London 1975, s. 77 - 80.

${ }^{40}$ Por. K. R o m a ni u k, List do Rzymian, Poznań-Warszawa 1978, s. 132. 
może zawieść", gdyż miłość Boża rozlana jest w naszych sercach przez Ducha, który został nam dany ${ }^{41}$. Duch Święty rozlewa w sercach miłość, która jest potwierdzeniem nadziei chrześcijańskiej - częściowym uczestnictwem w dobrach, które kiedyś w pełni otrzymamy —źródłem siły do wytrwałego praktykowania wypróbowanej cnoty.

Zostaliśmy usprawiedliwieni przez krew Chrystusa (Rz 5,9), który „umarł za nas, jako za grzeszników, w oznaczonym czasie, gdyśmy (jeszcze) byli bezsilni” $(5,6)$. Nasza nadzieja nie może zawieść, bo miłość Boża jest rozlana w naszych sercach przez Ducha Swiętego, który został nam dany (w. 5). Obok siebie stoją ofiara i Duch: ofiara jako czyn doskonałej miłości i Duch, który rozlewa tę miłość w obecnym porządku jako zadatek przyszłych rzeczywistości i rękojmię, która nie może zawieść ${ }^{42}$. Ofiara została dokonana w oznaczonym czasie: gdy nadeszła pełnia czasów (por. Ga 4,4; Ef 1,107 - wyznaczony przez Boga moment do realizacji Jego zbawczego planu. Została dokonana raz na zawsze (por. Hbr 9,12).

„Bóg zaś okazuje nam swoją miłość (właśnie) przez to, że Chrystus umarł za nas, gdyśmy byli jeszcze grzesznikami” (Rdz 5,8). Miłość Boża przekracza wszelkie ludzkie miary. Św. Paweł mówi o miłości Boga — nie tylko miłości samego Chrystusa, lecz miłości całej Trójcy: przede wszystkim Ojca, który nieskończenie miłuje swego Syna (por. Ef 1,6), a także Ducha Świętego, Bożej Myśli i Bożej miłości. Rz 5,5 mówi o rozlewaniu miłości w ludzkich sercach jako o podstawowym działaniu Ducha w ochrzczonych ludziach. Miłość należy do istoty Trzeciej Osoby Boskiej i każde dzieło Bożej Miłości jest związane z Jej działaniem ${ }^{43}$. Dlatego i tu - w ofierze Chrystusa, jest na nie miejsce.

Odkupienie przez krew Chrystusa wysławiane jest także w hymnie ku czci tajemniczego Bożego planu zbawienia w Ef 1: „Bóg i Ojciec Pana naszego Jezusa Chrystusa... z miłości przeznaczył nas dla siebie jako przybranych synów przez Jezusa Chrystusa” (w. 3.5). „W Nim mamy odkupienie przez Jego krew —odpuszczenie występków według bogactwa Jego łaski” (w. 7). „W Nim także uwierzyliście i zostaliście naznaczeni pieczęcią Ducha Świętego, który był obiecany" (w. 13). O Duchu Świętym jako Bożej pieczęci mówi też Ef 4,30, a wcześniej 2 Kor 1,22. Plan Bożej miłości jest dziełem Ojca — dokonanym w Chrystusie Jezusie. Przez Niego otrzymaliśmy wszystkie łaski umożliwiające nam zbawienie, zawarte w darze Bożego dziecięctwa ${ }^{44}$.

${ }^{41}$ Dar Ducha Bożego jest znakiem miłości Boga do człowieka i jednocześnie należy do przyszlych rzeczywistości, które są już blisko - podobnie jak znakiem ostatecznych czasów są uciski i prześladowania Ludu Bożego; por. C. K. B a r re t t, A Commentary..., s. 104 n.

${ }^{42}$ Por. A. Jan k ow k i, Sens trzech przenośni Pawtowych: „Pierwsze dary” - „zadatek”„pieczętowanie” (Rz 8,23; 2 Kor 1,22; 5,5; Ef 1,13 n; 4,30), „Sląskie Studia Historyczno-Teologiczne" 4(1971) s. $23-37(26-32)$.

43 Por. T. Dą be k, He Agape tou Pneumatos, „Analecta Cracoviensia” 15 (1983), s. 105 $121(118.120)$.

${ }_{44}$ Zawierają się one w darze Bożego dziecięctwa; por. A. ja n k ow ski, Listy więzienne..., s. 367; tenże, Sens trzech przenośni..., s. $26-32$. 
W Ef 1,12 jest także mowa o naszej nadziei złożonej w Chrystusie. Duch Swięty jest pieczęcią naszej przynależności do Chrystusa i „zadatkiem naszego dziedzictwa w oczekiwaniu na odkupienie, które nas uczyni własnością (Boga), ku chwale Jego majestatu" (w. 14). Znów widzimy podział zakresów działania dwóch osób Boskich: w Synu - Panu naszym Jezusie Chrystusie (por. w. 3), Bóg dokonał wszystkich dzieł związanych z naszym odkupieniem do opieczętowania Duchem Swiętym włącznie (w. 13 - grecki tekst: esfragisthète tō pneúmati mówi wyraźniej niż polski przekład w ostatnich wydaniach $\mathrm{Bi}$ blii Tysiąclecia, że sam Duch jest pieczęcią), według postanowienia, które przedtem w Nim powziął dla dokonania pełni czasów" (w. 9 n). Teraz w obecnym eonie, trwającym od Wniebowstąpienia, a raczej od Zesłania Ducha Świętego w dniu Pięćdziesiątnicy do powtórnego przyjścia Chrystusa w chwale, jest czas działania Ducha Świętego, którego obecność w każdym $\mathrm{z}$ ochrzczonych jest znakiem przynależności do Boga i zadatkiem pełni odkupienia - zjednoczenia z Bogiem ${ }^{45}$.

Rola Ducha Swiętego pokazana jest na etapie włączania ludzi w zbawcze dzieło Jezusa Chrystusa przez chrzest, co nie znaczy, że wcześniej nie działał On razem z Jezusem - w czasie Jego ziemskiego życia — i jeszcze wcześniejjako Boża Mądrość, od której pochodzą Boże zamiary i Boża miłość, źródło Bożych postanowień, a w szczególności tego, że przeznaczył nas dla siebie jako przybranych synów (w. 5). Tytuł przybranych synów to szczególny znak Bożej miłości - wprowadzenie między Bogiem i ludźmi stosunków rodzinnych, opartych na wzajemnej miłości - czegoś więcej, niż tylko troska Stwórcy o Jego dzieło. Jest to osobowe zjednoczenie analogiczne do związków krwi cielesnego pochodzenia, kiedy to rodzice traktują dzieci jako cząstkę samego siebie - własnej osobowości.

Z ofiarą zbawczą Jezusa Chrystusa nierozdzielnie związane jest jego zmartwychwstanie. W porównaniu do tekstów mówiących o krwawej ofierze Syna Bożego, gdzie wzmianek o działaniu Ducha Świętego jest stosunkowo niewiele, teksty o zmartwychwstaniu kilkakrotnie podkreślają rolę Trzeciej Osoby Boskiej we wskrzeszeniu Jezusa Chrystusa do nowego życia. W Rz 1,3 n czytamy, że Ewangelia głoszona przez św. Pawła to Dobra Nowina „o Jego (Boga) Synu - pochodzącym według ciała z rodu Dawida, a ustanowionym według Ducha Świętości przez powstanie z martwych pełnym mocy Synem Bożym". Przez powstanie z martwych za sprawą Ducha Świętego godność Bożego Synostwa przysługująca Jezusowi Chrystusowi, stała się jawną dla wszystkich ${ }^{46}$.

Podobny sens ma hymn chrystologiczny z 1 Tm 3,16: „Ten, który objawil się w ciele, usprawiedliwiony został w Duchu, ukazał się aniołom, ogłoszony 32.

${ }^{45}$ Por. A. J a n k ow ski, Listy więzienne..., s. 378 n; tenże, Sens trzech przeności..., s. 26 -

${ }^{46}$ Por. C. K. B arrett, A Commentary..., s. 19 n; H. Sch lie r, Der Römerbrief, FreiburgBasel-Wien 1977, s. 23-27. 
został poganom, znalazł wiarę w świecie, wzięty został w chwale”. Duch to nie tylko przeciwieństwo ciała, lecz Duch Boży, posiadający życiodajną moc (por. $\mathrm{J} 6,63 ; 1 \mathrm{P} 3,18$ ), zdolną spowodować powstanie $\mathrm{z}$ martwych ${ }^{47}$. On potwierdza sprawiedliwość, czyli świętość Chrystusa przez zmartwychwstanie, a także przez Jego życie i czyny dokonane w mocy Ducha. Ta sama moc sprawi też zmartwychwstanie ludzi wierzących w Jezusa (por. Rz 8,11) ${ }^{48}$ - Pana i Zbawiciela.

W 1 P 3,18 czytamy, że „Chrystus... raz umarł za grzechy, sprawiedliwy za niesprawiedliwych, aby was do Boga przyprowadzić; zabity na ciele, ale powołany do życia Duchem”. Wieczna, niezniszczalna, niebieska sfera Ducha, to rzeczywistość nowego życia po zmartwychwstaniu ${ }^{49}$. Duch niesie w sobie życie, udziela życiodajnej mocy, przywraca siłę żywotną w tym nowym życiu następującym po cielesnej śmierci dla chwały Boga i zbawienia ludzi ${ }^{50}$.

Ten sam Duch, który powołał do nowego życia umęczone ciało Jezusa Chrystusa, tworzy także jego ciało eklezjalne, jest zasadą jego jedności, której szczególnym znakiem jest także Eucharystia (por. 1 Kor 10,16 n). Ci, którzy uczestniczą w Ciele i Krwi Chrystusa są w jedności z Nim i między sobą, tworząc jedno Ciało (1 Kor 10,17) jako „w jednym Duchu ochrzczeni” i „napojeni jednym Duchem" $(1$ Kor 12,13). Ten sam Duch udziela różnych darów dla pożytku całego Ciała (por. 1 Kor 12,4-6). Ludzkie posługiwanie staje się w ten sposób kontynuacją dzieła Tego, który stał się Sługą Jahwe (por. Dz 3,13.26; 4,27.30). Przez Niego w jednym Duchu mamy przystęp do Ojca (Ef 2,18) wezwani spośród Żydów i pogan do nowego, duchowego życia.

Rola Ducha jako zasady jedności członków Chrystusowego Ciała wyraża się szczególnie poprzez określenie „wspólnota Ducha - wspólnota w Duchu” — koinōnía tou pneúmatos, związanym również z Eucharystią jako sakramentem jedności ${ }^{51}$. Termin koinōnia w 1 Kor 10,16 określa eucharystyczny udzial we Krwi i Ciele Chrystusa, w Flp 2,1 - udział w Duchu, w 1 J 1,6 - nasze współuczestnictwo z Bogiem, w 1 Kor 1,9 — naszą wspólnotę z Jezusem Chry-

${ }^{47}$ Por. C. K. B arrett, The Pastoral Epistles, Oxford 1963, s. 64 n; D. G u r th i e, The Pastoral Epistles, London 1964, s. 89 n; J. D. Q u in n, The Holy Spirit in the Pastoral Epistles, [w:] Sin, Salvation and the Spirit, ed. D. D u r k e n, Collegeville 1977, s. 345 - 368 (355).

${ }^{48}$ N. Brox, Die Pastoralbriefe, Regensburg 1969, s. 159; por. J. Je re mi as, Die Briefe an Timotheus und Titus, [w:] A. Str o be 1, Der Brief an die Hebräer, Göttingen 1975, s. 27.

49 Por. określenie sóma pneumatikón w 1 Kor 15,44 oraz: F. W. B e a re, The First Epistle of Peter, Oxford 1961, s. 141 - 143; E. B es t, I Peter, London 1971, s. 139; R. F a bri is, Lettera di Giacomo, [w:] Prima Lettera di Pietro, Bologna 1980, s. 242; N. B r o x, Der erste Petrusbrief, Zürich-Einsiedeln-Köln-Neukirchen-Vluyn 1979, s. 168.

50 Por. E. G. Selw y n, The First Epistle of St. Peter, London 1947, s. 197; R. F r a t ta lou, Fondamenti dell' agire morale secondo la $1^{a}$ Pt. Il battezzato sulle orme di Cristo, Bologna 1971, s. 134; C. S pic q, Les epîtres de Saint Pierre, Paris 1966, s. 136; K. H. S ch el k le, Die Petrusbriefe. Der Judasbrief, Freiburg-Basel-Wien 1961, s. 104. Podobny sens ma też Rz 6,4: Duch jako „chwała Ojca".

51 Por. J. Hain z, Koinōnia. „Kirche” als Gemeinschaft bei Paulus, Regensburg 1982, s. 35. Autor zwraca uwagę na określenie z 1 Kor 10,16: koinōnía tou sōmatos tou Christou, analogiczne do wspólnoty Ducha z 2 Kor 13,13. Por także: J. E. Co m ming, Through the Eternal Spirit. A Bible Study on the Holy Ghost, London (1966), s. 235. 
stusem, w Flm 6 i 1 J 1,3.7 związek we wspólnej wierze, w Ga 2,9 i Flp 1,5 współudział w jednym posługiwaniu, w 2 Kor 6,14; Dz 2,24 i Flp 3,10 ten sam los, w Dz 2,24; Rz 15,26; 2 Kor 8,4; 9,13 i Hbr 13,16 — solidarność zobowiązującą do niesienia pomocy.

Przytoczone wyżej teksty ukazują działanie Ducha w tworzeniu Kościoła - najpierw Jego współudział w zbawczym dziele Jezusa Chrystusa, Arcykapłana i Ofiary Nowego Przymierza, konstytuującego Nowy Lud Boży jako swoje Ciało, a następnie kontynuację tego faktu dokonanego raz na zawsze w życiu Chrystusowej wspólnoty 52 . Teraz rozważymy teksty mówiące o Pamiątce Chrystusa - uobecnieniu Jego Arcykapłańskiej ofiary i postaramy się wykazać związek tej Pamiątki z mocą Ducha ożywiającego Kościół.

\section{EUCHARYSTIA CENTRALNYM AKTEM KULTU NOWEGO PRZYMIERZA W DUCHU ŚWIĘTYM}

Ewangelie synoptyczne oraz św. Paweł w Pierwszym Liście do Koryntian podają opisy ustanowienia Eucharystii w przeddzień Męki Pańskiej (Mt 26,26 - 28; Mk 14,22 - 24; Łk 22,19-20; 1 Kor 11, 23-25). Przekazy te mówią, że ziemski pokarm i napój stają się prawdziwym Ciałem i Krwią Chrystusa. Najstarszy chronologicznie i teologicznie najbardziej rozwinięty tekst św. Paw$\mathrm{la}^{53}$ zawiera dwukrotnie powtórzony nakaz: „To czyńcie na moją Pamiątkę”jako ofiarnicze uobecnienie Jego oddania się za nasze grzechy ${ }^{54}$. Ogromną godność tego obrzędu, dzięki któremu spożywa się prawdziwe Ciało Pana i pije Jego prawdziwą Krew, podkreśla Apostoł Narodów piętnując nadużycia, jakie zaistniały w Kościele korynckim: „Ilekroć bowiem spożywacie ten chleb albo pijecie kielich, śmierć Pana głosicie, aż przyjdzie. Dlatego też kto spożywa chleb lub pije kielich Pański niegodnie, winny będzie Ciała i Krwi Pańskiej” (1 Kor 11,26 n).

Wspólne schodzenie się na „łamanie chleba” było najistotniejszym rysem życia pierwszych chrześcijan. Określenie to często wskazuje na Eucharystię, choć może też oznaczać zwykły posiłek ${ }^{55}$. Występuje w Łukaszowym opisie ustanowienia Eucharystii $(22,19)$, w pierwszym „summarium” $(\mathrm{Dz} 2,42)$, relacji z pobytu św. Pawła w Troadzie (Dz 20,7) oraz w innych tekstach, gdzie najprawdopodobniej nie posiada żadnego odniesienia do Pamiątki Pana (Łk 24,30.3556; Dz 27,35).

52 Por. J. E. Y at es, The Spirit and the Kingdom, London 1963, s. 210.

53 Por. C. K. B a rre t t, The First Epistle to the Corinthians, London 1973, s. 5.

${ }^{54}$ Por. F. Che nderlin, Do this as my Memorial, Roma 1982, s. 217; A. Jan k ow sk i, Eucharystia jako ,nasza Pascha” (1 Kor 5,7) w teologii biblijnej Nowego Testamentu, „Ruch Biblijny i Liturgiczny" 28 (1975) s. $89-100$. (97).

55 Por. K. R om a niuk, „Łamanie chleba”, tamże 40 (1987) s. 1-7.

56 Mówi się też o wplywie liturgii na redakcję Łk $24,13-35-$ por. R. Orlet t, An Influence of the Early Liturgy upon the Emmaus Account, CBQ 21 (1959) s. 212 - 219. 216 n; J. A. G r as si, 
Chrystus ustanawiając swoją Pamiątkę, działał w Duchu, który Go napełniał od chwili poczęcia w łonie Matki, nie znającej pożycia z mężem (por. Łk 1,34 n; Mt 1,18.20). Duch Boży to mądrość, światło, siła stwórcza, obecna przy stwarzaniu świata (unosząca się nad bezładem materii, by potem organizować ją w wielorakie formy, które wszystkie były bardzo dobre - por. Rdz 1,31). Ten Duch sprawia, że nasza modlitwa jako członków Kościoła - Ciała Chrystusa, jednoczy się z Jego ofiarą i nabiera nadprzyrodzonej mocy ${ }^{57}$.

Eucharystia - przemiana jednej rzeczywistości w inną: ludzkiego pokarmu i napoju w prawdziwe Ciało i krew Syna Bożego, to także manifestacja twórczej mocy Bożej - odnawiającej i przemieniającej. Bożym — Duchem dziełem jest przemiana stworzenia - nowe stworzenie chrześcijan na chrzcie (odrodzenie - narodzenie na nowo z wody i Ducha - por. J. 3,5) ${ }^{58}$. Eucharystyczna przemiana to nie tylko nadanie nowej nazwy, wprowadzenie symbolu, ale rzeczywiste przekształcenie materialnych darów w to, co składa się na ludzką naturę Jezusa Chrystusa - Wcielonego Syna Bożego - dla dobra wspólnoty wierzących ${ }^{59}$.

Eucharystyczna Pamiątka i uczta odpowiada rzeczywistości i symbolice innych kultów a w szczególności kultu Starego Przymierza, gdzie spożywanie części ofiary było szczególnym sposobem zjednoczenia - wspólnoty z Bogiem uczestnictwa w Jego przymierzu. Nowe, duchowe przymierze, też ma ofiarę, lepszą od ofiar Dawnego prawa (por. Hbr 9,9-14). Ta ofiara również wiąże się z ofiarnym posiłkiem, przemieniającym człowieka, tak jak przemienia go obecność Ducha ${ }^{60}$. Ofiara jest Tym samym, co Arcykapłan, który przez Ducha wiecznego przeszedł przez zasłonę swego ciała (por. Hbr 10,20) i przez Ducha uobecnia swoją ofiarę tym, którzy w Duchu są z Nim zjednoczeni. To jest prawdziwy kult w Duchu i prawdzie - centrum życia Kościoła, źródło nowego, nieustannie odnawiającego się życia ${ }^{61}$ i najdoskonalszy na tej ziemi sposób zjednoczenia członków eklezjalnego Ciała z Głową.

Opisy ustanowienia Eucharystii z Ewangelii Synoptycznych i 1 Kor 11 uzupełnia mowa eucharystyczna w szóstym rozdziale Ewangelii św. Jana ${ }^{62}$, gdzie

Emmaus Revisited (Luke 24,13 - 35 and Acts 8,26 - 49), CBQ 26 (1964) s. 463 - 467 (463 n).

57 Por. S. W. Sykes, Sacrifice in the New Testament and Christian Theology, [w:] M. C. F. Bourdillong, M. Fortes (red.), Sacrifice, London 1980, s. 61 - 83 (77).

58 Por. I. Go má Civit, „Ubi Spiritus Dei, illic Ecclesia et omnis gratia” (Iren. Adv. Haeres. III, 24,17. El Espíritu Santo y sus „carismas” en la Teologia del Nuevo Testamento, Barcelona 1954, s. 41.

${ }^{59}$ Por. G. W. H. La m pe, God and Spirit, Oxford 1977, s. 194.

60 Por. J. R. Villalón, Sacrements dans l'Ésprit, Paris 1977, s. 435; W. R obin so n, The Christian Experience of the Holy Spirit, London 1942, s. 213.

${ }^{61}$ Por. A. Frid ricks e n, Eglise et sacrement dans le Nouveau Testament, „Revue d'Histoire et de la Philosophie Religieuse" 17 (1937), s. 337 - 356 (344).

62 Janowa nauka uzupełnia i wyjaśnia sens synoptycznych i Pawłowego przekazów ustanowienia Eucharystii, znanych uczniom Jana do tego stopnia, że nie trzeba było ich powtarzać $w$ zwartej Ewangelii; por. R. E. B rown, The Community of the Beloved Disciple, New York-RamseyToronto 1979, s. 21. Zwraca się także uwagę na liturgiczną genezę J 6 - jego związek z chrześcijańską homilią (haggadą) paschalną; por. E. J. Kil m a r t i n, Liturgical Influence on John 6, CBQ 22 (1960) s. $183-191$. 
przez podkreślenie związku Ciała i Krwi Chrystusa z nowym życiem wierzących, szczególnie wyraźnie uwidacznia się więź Eucharystii, przy pomocy której Chrystus żywi swój Kościół ${ }^{63}$, z nowym porządkiem zbawczym, stanowiącym po odejściu Chrystusa do Ojca pole działania Ducha Świętego ${ }^{64}$.

Mowa eucharystyczna w J 6 następuje po cudzie rozmnożenia chleba zapowiadającym inny, doskonalszy chleb. Podstawą uczestnictwa w nowej rzeczywistości zbawczej jest wiara w Jezusa (J 6,29). Żydzi domagają się znaku potwierdzającego Boskie posłannictwo Jezusa i przypominają, że w przypadku Mojżesza - pośrednika Pierwszego Przymierza - jednym ze znaków był cudowny pokarm na pustyni - manna, nazywana przez $\mathrm{Wj} 16,4$. $13-15$ i Ps 78,24 „chlebem z nieba” (por. Mdr 19,21). Jezus odpowiedział: „Zaprawdę, zaprawdę powiadam wam: Nie Mojżesz dał wam chleb z nieba, ale dopiero Ojciec mój da wam prawdziwy chleb $\mathrm{z}$ nieba. Albowiem chlebem Bożym jest Ten, który z nieba zstępuje i życie daje światu” (J 6,32 n). „Jam jest chleb życia. Kto do Mnie przychodzi, nie będzie łaknął; a kto we Mnie wierzy, nigdy pragnąć nie będzie” (w. 35). „Jam jest chleb życia. Ojcowie wasi jedli mannę na pustyni i pomarli. To jest chleb, który z nieba zstępuje: kto go spożywa, nie umrze. Ja jestem chlebem żywym, który zstąpił z nieba. Jeśli kto spożywa ten chleb, będzie żył na wieki. Chlebem, który Ja dam, jest moje ciało za życie świata" (w. $48-51$ ). Ciało Jezusa występuje jako ofiara za życie świata i jednocześnie życiodajny pokarm.

Spożywanie Ciała i Krwi Jezusa jest nieodzownym warunkiem życia wiecznego. Jego Ciało i Krew są prawdziwym pokarmem i napojem umożliwiającym zjednoczenie z Chrystusem - trwanie w Nim (por. w. 53-59).

Bardzo ważne są słowa Jezusa, uzupełniające i wyjaśniające uczniom treść mowy eucharystycznej, bardzo trudnej do zrozumienia i przyjęcia dla wielu słuchaczy (por. J 6, 60.66): „Duch daje życie; ciało na nic się nie przyda. Słowa, które Ja wam powiedziałem, są duchem i są życiem" (6,63 por. Rz 8,1 14; Ga 5,16-26). W tym „duchowym” kontekście — pamiętając, że Słowa Jezusa są Duchem i życiem, że Bóg (Pan) jest Duchem (por. 2 Kor 3,17), że sam Jezus jest najściślej zjednoczony z Duchem, że On sam jest Słowem, które stało się Ciałem (J 1,14) i że Duch jest Dawcą życia (por. 2 Kor 3,6), rozważymy słowa Jezusa o Jego życiodajnym Ciele i Krwi65.

Słowo Jezusa daje życie (por. J 6,63). Boże dzieło polega na wierze w Jego Słowa - w Niego samego jako posłanego od Ojca (por. J 6,29). On jest Słowem Bożym (J 1,1) - Słowem Ojca. Posłany przez Ojca Syn-Słowo, niosący

${ }^{63}$ Por. J. C a m bi i r, Le grand mystère concernant le Christ et son Eglise, Ephesiens 5, 22 - 33, „Biblica” 47(1966) s. $43-90.223-242.79$.

${ }^{64}$ Por. H. S ch ü r m a n n, John 6,51 c-ein Schlüssel zur johanneischen Brotrede, BZ 2 (1958) s. $244-263.261$.

${ }^{65}$ Chrystus paschalny, posiadający pełnię Ducha, udziela Go swoim wiernym także przez Eucharystię, będącą również sakramentem Ducha, który przemienia ciało; por. J. Gible t, L'Eucharistie dans l'Evangile de Jean. Une lecture de Jn 6, „Concilium” 40 (1968) s. 55 - 62. 
w sobie pełnię życia - życiodajnej siły Bożej ${ }^{66}$, da prawdziwy chleb z nieba: różny - lepszy od pierwszego chleba z nieba (J 6,32) — manny, cudownego pokarmu na pustyni, który przez wiele lat utrzymywał przy życiu cały, liczny lud (por. Wj 16,35). Warto tu przypomnieć obietnicę daną Abrahamowi, że jego potomstwo będzie liczne jak ziarnka pyłu ziemi $(\mathrm{Rdz} 13,16)$ zrealizowaną w pierwszym Izraelu, żywionym manną na pustyni i w nowym potomstwie Abrahama - w tych, „którzy polegają na wierze” (Ga 3,7) i żywią się prawdziwym chlebem z nieba.

Nowym pokarmem życia ${ }^{67}$ nie będzie tylko materialna, ziemska rzeczywistość wzbogacona nowymi właściwościami, która zstępuje z nieba wyłącznie w sensie konkretnym, materialnym, jak deszcz, czy rosa opadająca z góry na ziemię (por. Wj 16,13 n). Będzie nim Ktoś, którego właściwą sferą bytowania jest niebo - dziedzina Boskich rzeczywistości — Jednorodzony Syn bytujący na łonie Ojca (por. J 1,18), który zstąpił z nieba i dla naszego zbawienia stał się człowiekiem. Teraz obiecuje nam On dać nowy, prawdziwy chleb z nieba źródło nowego, prawdziwego życia i najściślejszej jedności z Nim - z Jego Osobą ${ }^{68}$. Ta jedność jest wypełnieniem zapowiedzi Nowego Przymierza, głoszonej przez proroków ${ }^{69}$. Chleb z nieba będzie związany z kulminacyjnym punktem misji Syna - wydaniem Ciała za życie świata $(\mathrm{J} 6,51)$ na krzyżu ${ }^{70}$.

Zesłanie nowego chleba będzie dziełem zarówno Syna - Jezusa (J 6,51 „Ja dam”), jak - przede wszystkim - Ojca (6,33: „dopiero Ojciec mój da wam prawdziwy chleb z nieba"). Działanie Osób Boskich jest najściślej ze sobą powiązane: Pismo Święte kolejno określa te same rzeczy jako dary różnych Osób - tu Ojca i Syna. Kontekst ogranicza występowanie Osób Boskich w tym tekście tylko do Dwóch Pierwszych, lecz sposób wyrażania się natchnionych autorów nie pozwala wykluczyć, że chleb z nieba będzie również dziełem i darem Ducha, którego rola w stworzeniu i odkupieniu jest jasna na podstawie innych tekstów.

Ciało Jezusa było doskonałym narzędziem Ducha, przez które wypełnił się Boży zbawczy plan miłości. Eucharystia, to Jego Ciało, umożliwiające człowiekowi życie ${ }^{71}$, podobnie jak Jego nauka, pochodząca z duchowej sfery i do

${ }^{66}$ Por. H. van den Buss ch e, Jean, Bruges 1967, s. 227.

${ }^{67}$ Chlebem z nieba, dającym życie, którego nie zniszczy śmierć cielesna, tak jak duszy daje życie Slowo Boże; por. H. de Juill ot, Le pain de vie, BiVieChret 26 (1959) s. 38-43 (42); G. M. B e hle r, Le pain de vie, BiVieChret 32 (1960) s. 15-26 (16).

68 Por. J. S ch n eide r, Das Evangelium nach Johannes, Berlin 1978, s. 152; K. F. Nös ge n, Der Heilige Geist, sein Wesen und die Art seines Wirkens, Bd. 1, Berlin 1905, s. 250; A. A m b r oss a n i o, La dottrina eucaristica in San Giovanni secondo le recenti discussioni tra i protestanti, [w:] San Giovanni. Atti della XVII Settimana Biblica, Associazzione Biblica Italiana, Brescia 1964, s. $187-205.205$.

${ }^{69}$ Por. P. D a bi in, Le sacerdoce royal des fideles dans les Livres Saints, Paris-Gembloux 1941, s. 282; F. Gils, Désaltérés par l'unique Esprit, Paris-Freibourg 1982, s. 189.

70 Por. R. Schnackenburg, Das Johannesevangelium, Bd. 2, Freiburg-Basel-Wien 1971 , s. 95.

${ }_{71}$ Por. J. N. S anders, B A. Masti in, A Commentary on the Gospel according to St. John, London 1968, s. 197 n. 
niej wiodąca ${ }^{72}$. Słowa Jezusa są Duchem i życiem $(\mathrm{J} 6,63)$. Nie można tu kwestionować odniesienia do Ducha Świętego - ludzki duch nie daje życia (por. 2 Kor 3,6$)^{73}$. „Cielesne” - naturalistyczne rozumowanie nie wystarczy do zrozumienia i przyjęcia ofiary Chrystusa. Potrzebna jest tu moc Ducha, którego Jezus ześle po wniebowstąpieniu ${ }^{74}$. Trzeba przyjąć i zrozumieć słowa wypowiedziane przez historycznego Jezusa i przekazane za pośrednictwem świadków, gdyż one są nośnikami życia, jeśli w naszych sercach jest wiara, ożywiana przez Ducha ${ }^{75}$, który jest jednocześnie Duchem prawdy, a prawda wiąże się ściśle $\mathrm{z}$ życiem ${ }^{76}$.

Ciało samo z siebie jest niczym, ale napełnione Duchem staje się życiodajne $^{77}$ - otrzymuje moc dawania życia - staje się nośnikiem Ducha ${ }^{78}$. Przekazuje Jego życiodajną moc, która powołała do życia ukrzyżowanego Jezusa (por. Rz 1,4). Duchowy pokarm pozwala dążyć do prawdziwego życia i pokazuje, że Duch Święty jest Dawcą tej niosącej życie potęgi ${ }^{79}$.

Duch Swięty wzbudza w duszach ochrzczonych wiarę w Jezusa Chrystusa jako posłanego przez Boga Mesjasza, wiarę, że w Eucharystii jest Jego prawdziwe Ciało i Krew ${ }^{80}$. Tylko Duch Boży zna to, co Boskie, a my otrzymaliśmy tego Ducha (por. 1 Kor 2,11 n). Eucharystia może być owocnie przyjęta tylko przez tego, kto posiada Ducha Świętego i dzięki Jego pomocy może pojąć wielkość tego Bożego daru.

Chrystusowe Ciało obecne w Eucharystii jest rzeczywistością duchową: nie jest to ciało zmarłe, umęczone, lecz ciało zmartwychwstałe, powołane do nowego życia mocą Ducha, który jest zasadą nowego życia, charakterystycznym czynnikiem stanu po chrzcie, czyli uczestnictwa w nowym życiu zmartwychwstałego Chrystusa. Niektórzy uczeni dopatrują się w J 6,63 aluzji do pierwotnej epiklezy — wezwania Ducha Świętego podczas liturgii eucharysty-

72 Por. B. Lin d a rs, The Gospel of John, London 1972, s. 273.

73 Por. L. Morris, The Gospel according to John, Grans Rapids-Michigan 1971, s. 385; J. H. B e rn a rd (ed. A. H. McNeile), A Critical and Exegetical Commentary on the Gospel according to St. John, Edinburgh 1924, s. 218. Por. także 1 Kor 15,50; J. Jer emias, „Flesh and Body cannot inherit the Kingdom of God" (1 Cor XV, 50), NTS 2 (1955 - 56) s. 151 - 159 (159).

${ }_{74}$ Por. R. V. G. Ta sher, The Gospel according to St. John, London 1968; J. C. Fe n to n, The Gospel according to John, in the Revised Standard Version, Oxford 1970, s. 87; S. Schulz, Das Evangelium nach Johannes, Göttingen 1972, s. 111; L. S t a ch ow i a k, Ewangelia wedtug św. Jana, Poznań - Warszawa 1975, s. 221.

75 Por. A. Richardson, The Gospel according to Saint John, London 1960, s. 106; R. Sch na ck e n burg, Das Johannesevangelium..., Bd. 2 s. 107.

76 W. A. B a rry, The Spirit of Truth and of Life in John's Gospel, [w:] Contemporary New Testament Studies, red. M. R. R y a n, Collegeville-Minnesota 1965, s. $284-291$ (289 n.).

77 Por. A. M. Hu n t e r, The Gospel According to John, Cambridge 1965, s. 75; G. S pör r i, Das Evangelium nach Johannes, Bd. 1, Zürich 1950 , s. 130 n.; V. V a r n a ch, La realité symboliqie de l'Eucharistie, „Concilium” 40 (1968) s. 73 - 90 (87. 89).

78 A. Wike nhause r, Das Evangelium nach Johannes, Regensburg 1948, s. 107; por. V. Va r a ch, La realité symbolique de l'Eucharistie, „Concilium” 40 (1968) s. 73 - 90 (87. 89).

79 Por. J. S ch n eide r, Das Evangelium nach Johannes..., s. 156.

${ }^{80}$ Pelnia życia Ciala Chrystusa Zmartwychwstałego udziela się członkom Jego ciała (eklezjalnego); por. B. M. A hern, The Christian's Union with the Body of Christ in Cor., Gal., and Rom, CBQ 23 (1961) s. $199-209$ (205. 209). 
cznej jako osobowej Bożej mocy przemieniającej materialne postaci w prawdziwe Ciało i Krew Jezusa Chrystusa ${ }^{81}$.

Eucharystyczna jedność chrześcijan jest równoznaczna z jednością w Duchu. W 1 Kor 10 św. Paweł umieścił swoisty midrasz, w którym nazywa mannę i wodę cudownie wyprowadzoną ze skały duchowym pokarmem i napojem (pneumatikón brōma i poma - 1 Kor 10,3 n), zapowiadającym przyszłe rzeczywistości (w. 18). Sam Chrystus jest duchową skałą. Przymiotnik wskazujący na działanie Ducha Świętego w tej metaforze odnoszono do Trzeciej Osoby Boskiej w ciągu pierwszych czterech wieków istnienia Kościoła. W bieżącym stuleciu większość komentatorów była znacznie bardziej ostrożna, jednak ostatnio coraz częściej podkreśla się ścisłą więź omawianych określeń z działaniem Ducha, tak często występującym u św. Pawła ${ }^{82}$. W zestawieniu z określeniem „stół Pana”, który w 1 Kor 10, 21 Apostoł przeciwstawia „stołowi demonów", widzimy, że to Duch Pański przygotowuje nam na tym ofiarnym stole (por. Ml 1,12) nadprzyrodzony pokarm i napój. Mówiąc o wydarzeniach z czasów Wyjścia św. Paweł posługuje się terminologią znaną odbiorcom jego listu z ich nowego chrześcijańskiego życia, związaną z sakramentami chrztu i Eucharystii, po to, by tym mocniej uwydatnić godność środków zbawienia, jakimi Pan przez swego Ducha posługuje się dla dobra swego nowego ludu ${ }^{83}$. Życiodảjne działanie Bożego Ducha, które ocaliło Izraelitów (przodków) na pustyni, teraz daje nam środki do nowego życia poprzez zmartwychwstałe Jego mocą $(\mathrm{Rz} 8,11)$ Ciało Pańskie.

Działanie Ducha Świętego jako zasady jedności Kościoła - Ciała Chrystusa, powoduje te same skutki, co przyjmowanie Ciała i Krwi Pańskiej w Eucharystii - spożywanie z jednego stołu Pańskiego (por. 1 Kor 10,17). Duch także ożywia misyjną działalność Kościoła — głoszenie Dobrej Nowiny, które Jezus Zmartwychwstały, odchodząc do Ojca, zlecił swoim uczniom (Mt 28,10 - 20; Mk 16,15 - 18). Głoszenie Ewangelii to zarazem uwielbienie Chrystusa $(\mathrm{J} 16,14)$ - jedna z funkcji Ducha Parakleta, realizowana poprzez Jego obecność w głosicielach Dobrej Nowiny ${ }^{84}$. Jest to także eschatologiczne dopełnienie Bożego planu zbawienia ${ }^{85}$ przygotowanie ludzkości na powtórne przyjście Pana.

Można zestawić obok siebie nakaz misyjny oraz nakaz kończący formułę ustanowienia Eucharystii: „To czyńcie na moją Pamiątkę” (Łk 22, 19; 1 Kor 11, 24 n). Sam Zbawiciel będzie obecny z tymi, których wybrał (Mt 28,20), których otrzymał od Ojca, aby stanowili jedno z Nim, z Ojcem i między sobą (J 17,

${ }^{81}$ Por. P. Evdokimow, L'Esprit-Saint pensé les Pères et vécu dans la liturgie, [w:] H. Cazelle s, P. Evd o k im ov, A. G re in e r, Le mystère de l'Esprit Saint, Tours 1968, s. 69-109.

82 Por. A. J a k ow sk i, Duch Święty a Eucharystia..., s. 103.

83 Tamże.

${ }^{84}$ Por. J. López G a y, El Espíritu Santo y la misión, Bérriz-Vizcaya 1967, s. 54. 11.9.

${ }^{85}$ E. Sch weize r, The Church as the Missionary Body of Christ, NTS $8(1961-62)$ s. 1 - 
6. $20 \mathrm{n}$ ) i aby stali się zaczątkiem jedności świata — całego stworzenia — z Bogiem. Ich działanie ma być podobne do działania kwasu chlebowego, początkowo małej ilości dawnego ciasta, przemieniającego całą masę przygotowaną do nowego wypieku ${ }^{86}$.

Uczestnictwo w Eucharystii jest wypełnieniem nakazu pozostawionego przez Chrystusa uczniom - jest centralnym punktem nowego życia, źródłem siły do praktykowania przykazań miłości, do podejmowania trudów apostolskiej pracy, walki z własną słabością i do kontynuowania tego wszystkiego, co mistrz rozpoczął. To samo dzieło i wszystkie związane z nim wysiłki umożliwia obecność Ducha Świętego - obecność na mocy chrztu i bierzmowania, ale także szczególna obecność jako Ducha Chrystusa, zjednoczonego z Jego Ciałem i Krwią, obecnymi w Eucharystii ${ }^{87}$. Dlatego misja uczniów Chrystusa nie może obyć się bez ponawiania na Pamiątkę Pana Jego „łamania chleba” i ofiarowywania kielicha.

Podsumowając przedstawiony wyżej przegląd tekstów biblijnych oraz zawartych w nich idei, widzimy w Starym Testamencie coraz wyraźniejsze zapowiedzi nowego, duchowego kultu, związanego z napełnionym Duchem Pomazańcem Pańskim. Zapowiedzi te wypełniły się przez misję Jezusa Chrystusa, której szczytowym punktem była Jego Arcykapłańska Ofiara złożona Ojcu w Duchu Swiętym i ponawiana w Eucharystii. Pamiątka Pana w Najświętszym Sakramencie jest najwyższym wyrazem życia Kościoła w Duchu, który jako osobowa siła uświęca eklazjalne Ciało Pana, działając także w chwili dokonywania na ołtarzu eucharystycznej przemiany, tak jak działał w Jezusie Chrystusie podczas całego Jego ziemskiego życia. Teraz powoduje uobecnianie Ciała i Krwi Pańskiej na eucharystycznym stole oraz umożliwia owocowanie tego Najświętszego Sakramentu w życiu uczniów Chrystusa.

\section{DIE EUCHARISTIE UND DER HEILIGE GEIST \\ Bibeltheologische Verbindung}

\section{Zusammenfassung}

Die ostkirchlichen Schriftsteller verbinden oft die Wirkung des Heiligen Geistes mit der Eucharistie. Wir möchten die biblische Basis für diese Verbindung finden. In den letzten Jahren haben zwei Gelehrten über dieses Thema geschrieben: ein Dogmatiker J. M. R. Till a rd, L'Eucharistie et le Saint Esprit, NRT 90 (1968) S. 363- 387 und ein Biblist A. J a n k ow s ki, Duch Swięty a Eucharystia, „Analecta Cracoviensia” 8 (1976) s. 87 - 110. Wir möchten dieser Arbeit folgen

${ }^{86}$ Por. F. Gryglewicz, Ewangelia wedtug św. Łukasza, Poznań-Warszawa 1974, s. 250.

87 Uczestnictwo Ducha w przemianie eucharystycznych postaci w Ciało i Krew Chrystusa jest kontynuowane w życiu ludzi posilanych Najświętszym Sakramentem. Owocem tego jest ich postępowanie na drodze uświęcenia; por. Y. Con g a r, Je crois en l'Esprit Saint,t. 3, Paris 1980, s. 331 (339-341). Duch i Eucharystia są nierozłączne w życiu Kościoła jako dary łaski i źródła życia laski w ludzkich duszach; por. H. Mühle n, L'Esprit dans l'Eglise, t. 1, Paris 1969, s. 407 (9.37). 
und die biblische Texte über die Eucharistie und den Heiligen Geist untersuchen, um die Verbindung zwischen diesen zwei grossen Gottesgaben zu erleuchten.

1. Im AT kann man Ankündigungen der Eucharistie als eines geistigen Opfers und einer Opfernahrung in der Lehre vom neuen, vollkommenen Bund sehen. Der Alte Bund gab den Menschen nicht genug Kraft, damit sie den Anforderungen Gottes gerecht werden können. Die propheten Jeremia und Ezechiel sprechen über einen neuen, geistigen Bung zwischen Jahwe und seinem Volk (Jer 31, 31 - 34; Ez 11, 17-20; 36, 26-27). Im AT gibt es viele Ankündigungen einer neuen Heilsordnung. In dieser neuen Etappe wird es auch einen neuen, vollkommenen Kultus geben. Im AT hat Gott die alten Riten durch Moses gegeben, dem alles ,auf dem Berg” (vgl. Ex 26, $30 ; 27,8)$ gezeigt wurde. Diese Riten hatten aber nur dann einen Wert, wenn die Menschen nach Gottes Geboten lebten (vgl. Spr 21, 3; Hos 6,6; Ps 40, 7 - 9; 50, 16 ff; Sir 34, 17 - 18; Am 4, 4 $5 ; 5,22-26$; Jes 1, $10-20$; Jer 7, $22-23$ ). Der alte Bund hat sich als ungenügend erwiesen. Daher sprechen die Propheten über einen neuen, geistigen, vollkommenen Bund (Jer 31, 31 - 34; 32,

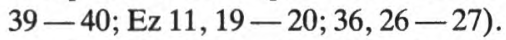

Der Gottesknecht - mit Gottes Geist gesalbt - wird sich selbst als ein neues Opfer für die Sünder hingeben (Jes 42, 1; 53, $4-5.8811$ ). An jedem Ort wird eine reine Opfergabe dargebracht (Mal 1, 11). Der Messias wird Priester auf ewig nach des Melchisedech Weise (Ps 110,4). Das Manna - die Nahrung der Israeliten in der Wüste - ist ein Zeichen einer neuen, geistigen Nahrung (Himmelsbrot - Ps 78, 24 ff; Weish 16, 20). Das messianistische Mahl und der Reichtum der Gottesgaben in der Messias-Zeiten sind Symbole der Einheit zwischen Gott und den Menschen in dieser messianischen zukunft.

Jesus Christus - Gottes Sohn - von Anfang seines menschlichen Lebens mit dem Heiligen Geist vereinigt (Mt 1, 18. 20; Lk 1, 35), hat alle alttestamentlichen Ankündigungen erfüllt. Er hat einen neuen Kultus im Geist und in der Wahrheit begonnen. Dieser Kultus ist mit dem Leben der Schüler Christi eng verbunden. Es ist ein neues, geistiges Leben, das Leben im Heiligen Geist, das mit der Taufe in der menschlichen Seele beginnt. Das ist derselbe Geist, der bei der Schöpfung tätig war und der auch jetzt die neue Schöpfung vollendet.

2. Der Höhepunkt der Heilsgeschichte ist das vollkommene Opfer des neuen Bundes, das der neue Hohenpriester als der einzige Mittler zwischen Gott und den Menschen (1 Tim 2,5; Hbr 9,1 $-5.14-15)$ für den Vater dargebracht hat. Seine hohenpriesterliche Würde und seine ganze messianische Sendung ist die Wirkung des Heiligen Geistes. Er ist die persönliche Gotteskraft, die die Liebe Gottes zu den Menschen enthüllt und die Gabe der heiligkeit verleiht. Christi Opfer ist der Höhepunkt seiner Wirkung als gesalbten Gottesknechts (Jes 42, 1). Der Geist ist auch der Täter der Auferstehung Christi (vgl. Röm 1, 4; 8, 11; 1 Kor 15, 45). Derselbe Geist hat den menschlichen Leib Christi auferweckt und verleiht seinem kirchlicben Leib das Leben.

3. Die Eucharistie als Christi Andenken ist der Höhepunkt des Lebens und der Wirkung der christlichen Kirche. Das Brot und der Wein werden in wahren Leib und in wahres Blut Christi gewandelt. Das ist die geistige Nahrung für die Menschen, die an Christus, an den Bund zwischen Gott und seinem Volk glauben. Die Eucharistie ist auch das höchste Zeichen des geistigen Lebens der Kirche, die Kraftquelle für die Erfüllung des Missionsbefehls, den Christus seinen Jüngern gegeben hat. Sie sollen eins sein, das Evangelium verkünden und in gegenseitiger Liebe - in der Liebe Christi (bgl. Joh 13,34) - leben. Der Heilige Geist ist auch die Kraftquelle für ein gutes, christliches Leben. Er wirkt auch besonders im Moment der eucharistischen Wandlung auf dem Altar und im Leben der Christen, damit sie Früchte der Eucharistie bringen können. 